\title{
The Importance of Soft Skill Development for Veterinary Technology Graduates and Veterinary Businesses
}

\author{
Danny Walker, DVM (Corresponding author) \\ Assistant Professor of Animal Science \\ Agriculture, Geosciences and Natural Resources, University of Tennessee-Martin \\ Brehm Hall 143, Martin, TN 38238, United States \\ Tel: 731-881-7328Ｅ-mail: dwalke41@utm.edu
}

Jason Roberts, DVM

Associate Professor of Animal Science

Agriculture, Geosciences and Natural Resources, University of Tennessee-Martin

Brehm Hall 253, Martin, TN 38238, United States

Tel: 731-881-7952Ｅ-mail: jroberts@utm.edu

Joey Mehlhorn, Ph.D.

Professor of Agribusiness

Agriculture, Geosciences and Natural Resources, University of Tennessee-Martin

Brehm Hall 254 Martin, TN 38238, United States

Tel: 731-881-7275 E-mail: mehlhorn@utm.edu

Received: September 20, 2015 Accepted: October 28, 2015

doi:10.5296/ber.v5i2.8328

URL: http://dx.doi.org/10.5296/ber.v5i2.8328

\begin{abstract}
Freshman veterinary technology students and practicing veterinarians were both surveyed to determine their perceptions of the importance of skills needed to be successful in a veterinary
\end{abstract}


technology career. Questions focused on distinguishing between soft business skills and technical skills. Findings indicated that practicing veterinarians prized teamwork skills as the overall most important trait in a potential employee. Students rated the ability to work in a group as important, but not as high as management skills. Students did recognize the importance of soft skills such as communication and conflict resolution. These findings confirmed students have mixed perspectives on the importance of technical versus soft skills in the veterinary technology industry. Students indicate that they understand the importance of business related skills in the profession. It is important that educators work to develop graduates who add soft skills to the traditional technical skills they receive in their program. Industry professionals value soft skills and in a competitive environment for employees, it will be important to prepare students to become industry ready graduates.

Keywords: Veterinary technology education, Soft Skills, Career readiness

\section{Introduction}

Today there is a renewed focus on developing industry ready graduates with the skill set required to be successful. Skills such as ability to function in a team environment, leadership, communication, work ethic and critical thinking are sought by employers (Engelkemeyer, 2012). The field of veterinary technology has growth potential and these graduates will need to satisfy the core needs of the industry. According to the Bureau of Labor Statistics Occupational Handbook the profession is projected to grow by 30 percent from 2012 to 2022, as more veterinarians require advanced technology to treat animals (Bureau of Labor Statistics, 2015). It will be essential that the veterinary technologist entering the workforce have the necessary skill set to be successful. In the past, a dichotomy often existed between students matriculating at traditional universities versus vocational colleges. Today, the lines between students being college ready and career ready are blurred. Today's successful students in any career need to be well prepared academically in particular the STEM (Science, Technology, Engineering, and Math) disciplines (Jackson, 2013). There is a growing shift in the labor force to include more jobs in the service related industries and an increased need for more people who can connect knowledge to problem solving skills (Hilton, 2008).

As tuition costs rise in the U.S., many students and parents are asking if higher education is worth the expense. Agriculture related programs are not immune to these types of questions and must defend the importance of enrolling in a veterinary technology undergraduate program. Most faculty and university recruiters will state that a university degree is valuable not only from a monetary point of view, but also from a personal development standpoint. Much of the advantages of higher education come from the general education (liberal arts) courses required for a degree. Studies have shown that employers are seeking employees that have critical and analytical reasoning, ethical decision-making, complex problem solving, and oral and written communication skills. Many of these skills are embedded in general education courses (Kliegl and Weaver, 2012). General education courses are assumed to help students build a foundation of knowledge needed to become effective employees. This foundation of knowledge is also important to the educational development required by students to understand the discipline specific knowledge of their chosen career (Laird and 
Garver, 2010). For example, a veterinary technology student may apply skills learned from a basic communications course to become proficient in obtaining animal medical history as taught in an upper division veterinary technology course.

Today many students enter the university with a clear career goal. For example, a student will cite the reason they chose the university is to be an accountant, engineer, or veterinarian. There are many factors affecting student's career choices including background, monetary reasons and personal interests. The student's career goal is a very effective academic motivator, but students may become disenfranchised with college when they learn they are required to complete general education courses in areas such as fine arts, history, and the sciences. As an educator, it is important to convey the value of the general education courses to the student's career goals. It is also essential to have effective career advising for entering students and to convey the interrelated nature of the overall education experience, not just the singular focus of a specific degree program. This information can be presented to students through freshman welcome week activities and introduction to college courses.

It is important for students who wish to pursue technical degree programs such as veterinary health technology plan early in their academic career for success. Since the degree is highly technical in nature, successful students must adapt to learning skills through experience. However, there is still a need for traditional academic courses such as math, science, and communication. Programs typically utilize a combination of didactic lectures to teach basic fundamental concepts and knowledge and then provide additional courses with an experiential component to teach technique. This combination is crucial in programs such as veterinary technology where students are required to possess a solid knowledge base in conjunction with a technical skill set.

\subsection{Soft Skills and Hard Skills}

Hard science skills tend to involve knowledge attainment with a quantitative focus. It is also typically teacher led where students are not actively engaged in the learning process (Robinson, 2009). Veterinary technology programs like most agriculture curriculums are a science based curriculum. The need for hard science skills cannot be underestimated by students or over emphasized by industry leaders. However, soft skills are also gaining in importance.

The development of soft skills is becoming increasingly more valuable among universities. Research has shown that the development of soft skills is of importance to the business profession (Leckey and McGuigan, 1997; Mitchell, et. al. 2010; Orr, et. al, 2011; Robinson, 2009). Soft skills can imply different things to different people, depending on the industry, specific field or context in which they are applied. Typically, the term soft skill will refer to the intangible skills that people possess outside of the technical skills. For example, the proper method for giving a dog an injection would be considered to be a technical skill while being able to speak with the dog's owner and comfort them through the process would be a soft skill. Maxine Kamin (2013) defines soft skills as covering a wide variety of areas such as interpersonal skills, communication (both speaking and listening), teamwork skills, and the ability to understand circumstances. These are all relevant skills that future veterinary 
technologists need in order to be successful in their career. The veterinary technology profession is very rigid with respect to developing technical skills as noted by the requirement to pass a professional licensing examination. While technical skills are easy to identify and teach, soft skills may be more elusive to develop or refine.

\subsubsection{Veterinary Health Technology Background}

The creation of the Veterinary Health Technology program at the University of Tennessee at Martin has been a success in both outreach and student enrollment. Some growing pains have been experienced that have strained resources. This has lead to a need for more long term planning by the department. It is possible to create new programs that reach a diverse audience while enhancing existing programs. In 2013, UT Martin developed a new program in veterinary health technology to meet industry demand and provide an alternative pathway for students interested in animal science careers. The success of the new program required administrative, faculty, and industry support. The program seeks to develop well-rounded graduates who understand technical and business skills. Business skills are becoming more vital as the cost of providing animal healthcare increases. Business skills are also essential for students who choose to work in fields tangential to veterinary medicine such as pharmaceutical sales or the pet care product industry.

\section{Materials and Methods}

This study attempts to assess perceptions of freshman students entering a four-year licensed veterinary technology program of qualities needed for success versus the characteristics desired by practicing veterinarians. The study also attempts to determine factors that influence student selection of a college major and career. These findings will help to better target recruitment efforts in the future to attract students. It will also aid universities and departments in better understanding that some students may not realize the magnitude of possessing certain skills that are essential to career success. It is also important that business training and soft skill development are increasingly integrated into student educational and training programs, in order to produce successful graduates that are well prepared and industry ready.

\subsection{Student Perspective}

An assessment was given to freshman students enrolled in a college orientation class at the beginning of the fall semester. All students who participated selected veterinary health technology as their expected major. Students $(n=58)$ enrolled in freshman general studies courses in the college of agriculture at the University of Tennessee at Martin were surveyed regarding their perceptions of general education courses and skills needed to be successful in their selected career choice. A 30-question survey was completed the first week of class during the fall 2014 and 2015 semesters. Student participants were selected from a similar demographic background. Question areas included demographic information, course specific information, career understanding, and expected outcomes from general education courses and discipline specific coursework. Soft skill traits were identified with respect to traits and business related skills needed to be successful in the profession. 


\subsubsection{Practitioner Perspective}

An assessment was given to practicing veterinarians in the state of Tennessee during the spring of 2015. The assessment focused on identifying the qualities that they considered to be essential for a veterinary technician. Veterinary responses $(n=123)$ to the questionnaire to assess which traits were the most important in the hiring of a veterinary health technologist were analyzed. Practitioners were asked to rate the traits as most important, important and least important. The three main traits were personality traits, professional traits, and technical skills. Under the traits, three criteria were considered for each main trait. Personality traits included friendliness, respectfulness, and kindness. The other main category of skills assessed was technical skills including laboratory skills, medication administration, and surgical assistance. Soft skills assessed under professional traits were communication, client education, and teamwork.

\section{Results}

All data was analyzed to determine descriptive statistics for students and practitioners. It was evident from the data that students and practicing veterinarians had differing responses and views on traits and skills essential for success.

\subsection{Student Findings}

Figure 1 shows results from the question: What factor most helped you in selecting your college major. Students were instructed to check only one response. As with many career decisions of students from the millennial generation (Taylor, 2013; White, 2015, and Miller, 2015), who are seeking purposeful labor, they largely selected personally rewarding as one of the top influences in choosing their major and career. Students tend to search for a major that will lead to a career that is meaningful to them. Income potential was the least important influence on their career choice selected by students. This reinforces the finding that financial motivation is not the main focus of career choice. Family was another strong factor for many students, which was not unexpected. This is expected since family tends to have a strong influence on students.

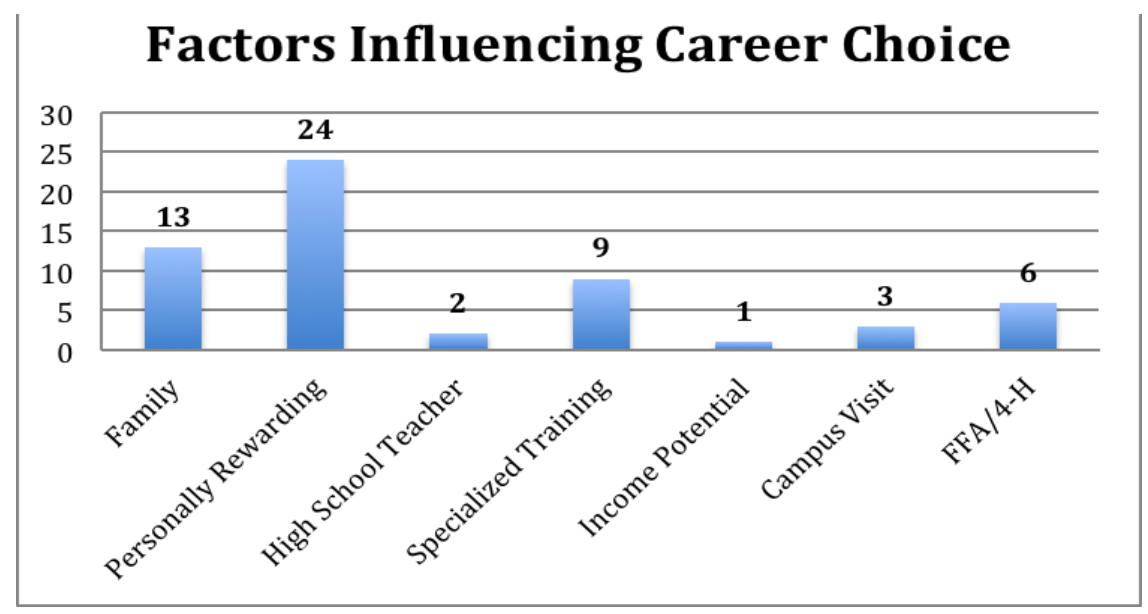

Figure 1. Factors Influencing Student Major Choice

There are some implications that universities should consider as a result. How can we as 
faculty better connect with parents during the recruitment process? This may be particularly important when dealing with first generation college students.

Table 1. Participation in FFA and 4-H Impact on Career Choice

\begin{tabular}{|c|c|c|c|c|}
\hline Participate & Yes & No & Did it influence your career & $\begin{array}{c}\text { Positive } \\
\text { Impact (\%) }\end{array}$ \\
\hline FFA & 18 & 40 & 16 & 88.88 \\
\hline 4-H & 21 & 37 & 12 & 57.14 \\
\hline
\end{tabular}

Table 1 revealed an evolving trend the authors are observing at their university regarding increased number of "non-traditional agriculture students" entering the program. The authors use FFA and 4-H participation as a proxy of students who are coming from an agriculture background. It is interesting that the majority of those individuals who participated in FFA in high school or $4-\mathrm{H}$ when younger indicated the programs had a positive impact on their career choice. This has important consequences for departments and universities as they recruit students in the future. Targeting agriculture youth programs is still a good place for recruiting efforts. National groups such as FFA and 4-H are providing more entrepreneurial and business training opportunities among their members. These programs can provide fertile ground for students who possess agricultural science skills and business skills. Today, students may be focusing on their career goals at an earlier age as college and career information is more easily accessible on the Internet. Today, students are also faced with many options for an academic major. The New York Times reported in 2010 that there were approximately 1,500 academic departments and degree programs in the U.S. (Simon, 2012). It may be reasonable for universities to begin recruiting efforts to students in elementary school and junior high while they are forming their career opinions.

Table 2. Soft and Business Skill Perceptions of Veterinary Technology Students*

\begin{tabular}{|l|c|c|c|c|c|c|}
\hline Course or Concept & 5 & 4 & 3 & 2 & 1 & AVG \\
\hline English & 6 & 6 & 15 & 13 & 18 & 2.47 \\
\hline Agribusiness & 6 & 19 & 19 & 10 & 4 & 3.22 \\
\hline Communication & 15 & 22 & 15 & 3 & 3 & 3.74 \\
\hline Time Management & 12 & 10 & 24 & 9 & 3 & 3.33 \\
\hline Computer skills & 28 & 19 & 9 & 1 & 1 & 4.24 \\
\hline Group skills & 28 & 20 & 6 & 3 & 1 & 4.22 \\
\hline Management skills & 46 & 7 & 4 & 0 & 1 & 4.67 \\
\hline Finance & 11 & 20 & 20 & 4 & 3 & 3.55 \\
\hline Accounting & 34 & 11 & 11 & 0 & 2 & 4.29 \\
\hline HR skills & 16 & 18 & 17 & 5 & 2 & 3.71 \\
\hline Conflict resolution skills & 14 & 13 & 22 & 6 & 3 & 3.50 \\
\hline
\end{tabular}

* (Very Important $=5$, Important $=4$, Neutral $=3$, Unimportant $=2$, Not necessary $=1)$

Table 2 results were mixed with management skills rating as the most important perceived business skill among students. This is promising that students understand the fundamental 
importance of management as a skill needed to be effective in their career. Accounting rated high as well at 4.29, indicating that students understand the importance of accounting to any business. This would not be surprising if the student pool was selected from a traditional business degree program. However, these students are enrolled in a science focused career path. The findings indicate that faculty should seek methods to incorporate business management into traditional veterinary technology courses when applicable. Soft skill communication rated highly among students. The authors expected the skills of time management, conflict resolution, and human resource skills to have been higher. Since most veterinary clinics work in a group setting (multiple staff and clientele) the students need to understand the importance of learning group dynamic skills early in their career. The students recognized the importance of group skills, with a high rating of 4.22. As with most career fields, conflict resolution is an essential skill when working with other people. This is imperative for people who will be working with the public and in potentially stressful or challenging environment such as a veterinary hospital.

Table 3. Technical Skill Perceptions of Veterinary Technology Students*

\begin{tabular}{|l|c|c|c|c|c|c|}
\hline Course or Concept & 5 & 4 & 3 & 2 & 1 & AVG \\
\hline Biology & 19 & 10 & 14 & 11 & 4 & 3.5 \\
\hline Chemistry & 17 & 7 & 14 & 13 & 7 & 3.24 \\
\hline Math & 8 & 11 & 19 & 11 & 9 & 2.97 \\
\hline Statistics & 1 & 13 & 15 & 16 & 13 & 2.53 \\
\hline Animal Science & 18 & 3 & 21 & 10 & 6 & 3.29 \\
\hline Plant Science & 15 & 17 & 19 & 5 & 2 & 3.66 \\
\hline Physics & 4 & 18 & 20 & 5 & 11 & 2.98 \\
\hline Soil Science & 30 & 10 & 13 & 4 & 1 & 4.10 \\
\hline
\end{tabular}

$*($ Very Important $=5$, Important $=4$, Neutral $=3$, Unimportant $=2$, Not necessary $=1)$

Table 3 results were surprising to the authors with soil science receiving the highest rating for importance among students. The expectation was that animal science, chemistry, and biology would have been perceived as the most important technical courses for the students. These findings show that students see the importance of technical training, but it is unclear if the students fully comprehend how the sciences relate to the required courses in the veterinary technology curriculum. Basic courses in the area of math are utilized in many upper division courses in the curriculum. This reinforces the notion that students can view knowledge acquisition in a vacuum while not understanding the full application of basic science skills. Biology and chemistry are similar in that basic science concepts are covered in these courses, but the application of the concept may not be apparent until students take upper division courses. In the future, it would be prudent to add veterinary technology specific courses to the list and compare student perceptions of those courses versus traditional science courses.

\subsubsection{Practitioner Findings}

Practitioners were asked to rate the traits as most important, important and least important. 


\section{MInstitute ${ }_{\text {Mnit }}^{\text {Macrothin }}$}

The three main traits were personality traits, professional traits, and technical skills. Personality traits included friendly, respectful, and kind. Results are summarized in Figure 2 below.

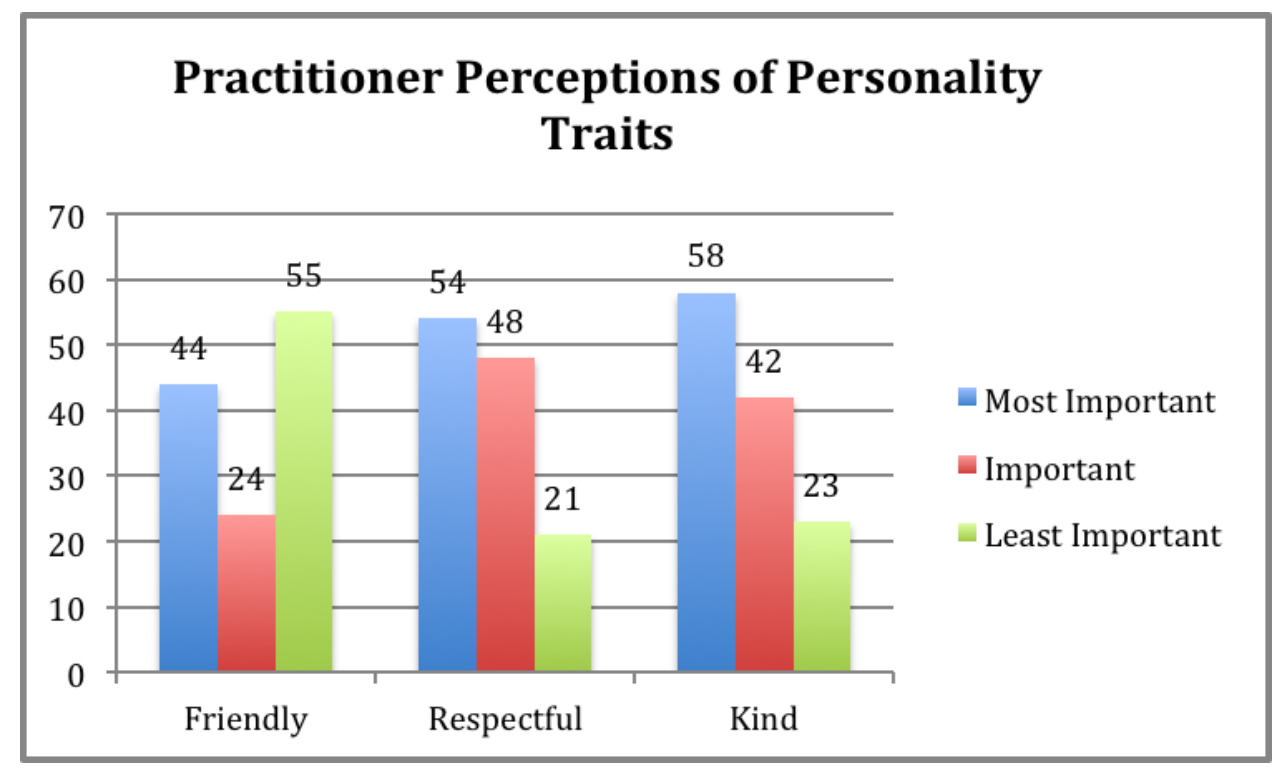

Figure 2. Practitioner Perceptions of Personality Traits

Surveyed veterinarians selected kindness as the most important personality trait overall. However, respectful was selected by 54 veterinarians surveyed. The data may be slightly misleading if the perspective is that an ideal employee would possess all three characteristics. Another possible issue with the question might be that the veterinarians may have not been clear whether it was in respect to interactions with clients or co-workers. It would be expected that most practicing veterinarians would desire all three traits to improve customer service with clients. The most interesting finding from the personality question is that Friendly was ranked as the highest number to be least important. The authors feel that this indicates that the surveyed veterinarians answered the question from the perspective of the employees working together versus working with clients.

Veterinarians were also asked about technical skills. Technical skills were classified as laboratory skills, medication administration, and surgery. These questions would be directly related to the employee's skill in performing the job. These skills are easier to assess than soft skills since effectiveness of these skills may be more standardized, or directly demonstrated through competent execution of tasks. Findings are summarized in Figure 3 below. 


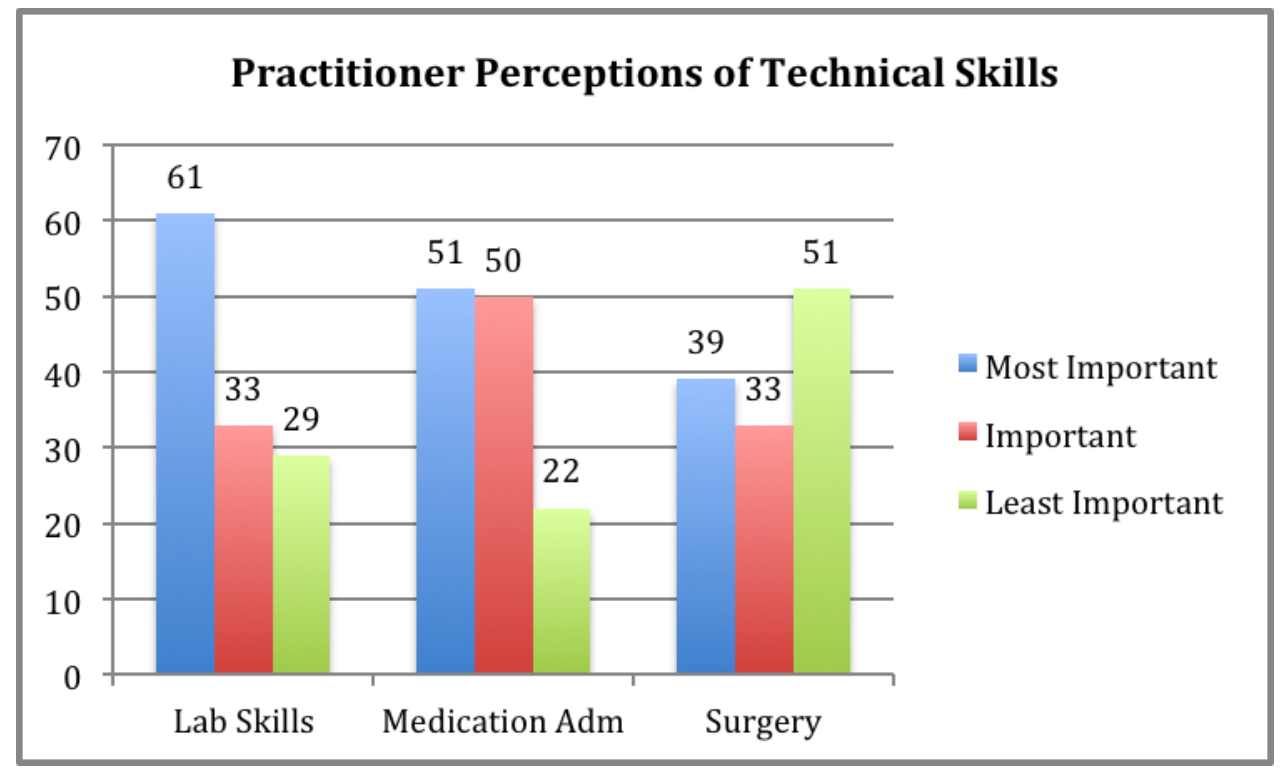

Figure 3. Practitioner Perceptions of Technical Skills

Veterinarians rated laboratory skill as the most important technical trait. This finding was consistent with the expectations of the authors. Laboratory work is a large part of the daily tasks of a veterinary technician. These skills also need to be performed with accuracy and efficiency. Surgery assisting skills were rated as the least important trait, probably because these skills are always used under the direct supervision by a veterinarian and many veterinarians tend to have their own unique preferences in relation to surgery practices and routines. A very interesting finding is that 101 surveyed veterinarians stated that medication administration is either most important or important. This indicates that a potential veterinary technician should focus on being efficient in medication administration. Faculty who teach in veterinary technology programs should be aware that this skill is highly prized by practicing veterinarians when selecting technicians. It should also be conveyed to students the importance of being able to complete basic math skills to dose and medicate patients properly, as the students rated the importance of math skills fairly low in this study.

Veterinarians were also asked about professional skills. Professional skills were classified as communication, client education, and ability to work in a team. These are soft skills that are needed by employees as they work in a customer service driven industry like veterinary medicine. These questions would be directly related to the employee's ability to interact with clients and work effectively in a multiple staff and diverse environment. These skills are directly observable by the veterinarian, but they are still subjective to some degree. Findings are summarized in Figure 4 below. 


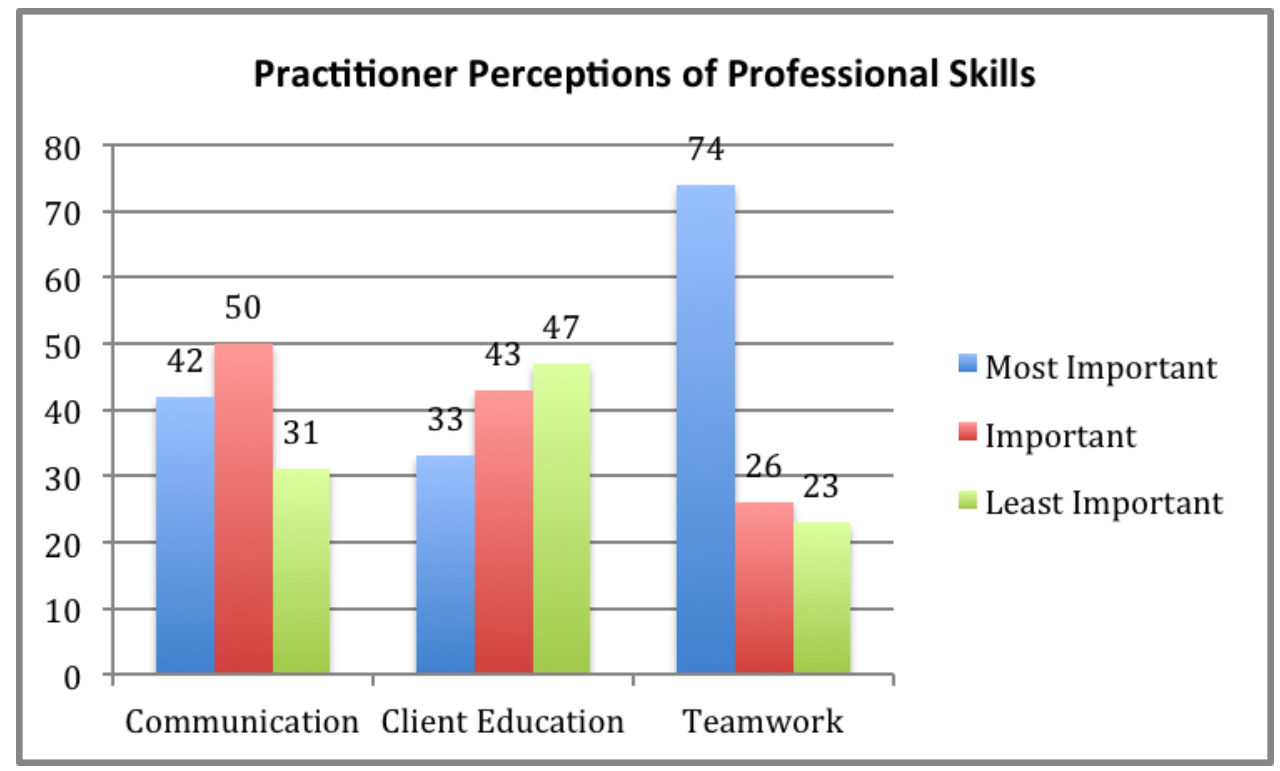

Figure 4. Practitioner Perceptions of Professional Skills

Teamwork ranked the highest under professional skills with 74 of the 123 veterinarians ranking it as most important. Results indicate that teamwork was the overall highest ranked trait among all three chategories. This finding has implications for faculty who educate and train future veterinary technologists. It is important that students learn to work effectively in a team environment. Development of teamwork as a skill may be overlooked in educational systems where grades tend to be focused soley on individual effort and testing. Many students tend to neglect the need for learning interpersonal skills such as teamwork. This is often identified as an isue when employees struggle with workplace conflict resolution with fellow employees. Client education tended to be lowest ranked trait in importance by veterinarians. This is possibly due to the fact that many veterinarians tend to consult directly with the client, which would reduce the need for tecnicians to routinely demonstarte proficiency of this skill. Overall, teamwork and communication both rated highly with respect to being important. These soft skills are areas that faculty can focus on in training future technologists.

\section{Conclusions and Implications}

Students ranked group skills highly (4.22/5.0) and the practicing veterinarians ranked it as most important. This is a significant finding in that students understand the value of learning to work in a team environment. Faculty should strive to develop teamwork and refine group skills among students. Currently, many programs focus heavily on hard technical skills. This is not a deficiency as students are expected to pass a board certification examination that will focus primarily on technical skills. The solution may be that faculty should no longer view the education process as dichotomous between development of technical and soft skills. Instead, focusing on producing well-rounded graduates with a universal set of technical, business and soft skills applicable to their field and better meet the needs of the specific industry. 


\section{MInstitute ${ }_{\text {Mnk }}^{\text {Macrothink }}$}

These findings will allow faculty to better understand the perceptions of the students entering veterinary technology programs and be better equipped to articulate the importance of soft skills along with discipline specific skills. Faculty can help reinforce the importance of business and soft skills in the veterinary technology profession by including these skill activities in their discipline specific courses. By understanding student perceptions, faculty will be better prepared for recruiting students into the discipline by targeting students who display aptitude for the needed soft skills in the industry. And finally, this study reminds faculty of the importance of relating to industry professionals when it comes to curriculum development. Industry advisory members can also help ensure the curriculum of educational institutions is current and fulfills the requirements the target industry or field, which has a vested interest in production of highly qualified and well-trained candidates.

\section{Acknowledgement}

The authors would like to thank the Tennessee Veterinary Medical Association for their valuable assistance with this project and the two anonymous reviewers for their insightful comments that have made this a better paper.

\section{References}

Bureau of Labor Statistics, U.S. Department of Labor, Occupational Outlook Handbook, 2014-15 Edition, Veterinary Technologists and Technicians, on the Internet at http://www.bls.gov/ooh/healthcare/veterinary-technologists-and-technicians.htm （visited August 14, 2015)

Engelkemeyer, Susan W. (2012). Getting our new graduates employed: A call for better job preparation during the undergraduate years, UB University Business, http://www.universitybusiness.com/article/getting-our-new-graduates-employed, July/August 2012 (Visited September 1, 2015)

Hilton, Margaret, Skills for work in the $21^{\text {st }}$ century: what does research tell us? Academy of Management Perspectives, volume 22, Number $4 \quad$ (2008). http://dx.doi.org/10.5465/AMP.2008.35590354

Kamin, Maxine. (2013) Soft Skills Revolution: A guide to connecting with passion for trainers, teams, and leaders, John Wiley and Sons, ISBN: 978-1-118-10037-0

Jackson, Nancy Mann. (2013). Career tech shifts to higher gear. District Administration, November, 36-41.

Kliegl, J. A., \& K. D. Weaver. (2012). Business education and liberal learning, PEER REVIEW, Spring: 28-30.

Laird, T. F., \& A. K. Garver. (2010). The effect of teaching general education courses on deep approaches to learning: how disciplinary context matters, Research in Higher Education, 51, 248-265. http://dx.doi.org/10.1007/s11162-009-9154-7

Leckey, J. F., \& M. A. McGuigan. (1997). Right tracks-wrong rails: the development of generic skills in higher education, Research in Higher Education, volume 38, number 3. 
http://dx.doi.org/10.1023/A:1024902207836

Miller, Adam. 3 Things millennials want in a career (hint: it's not more money)" Fortune Magazine

Online

http://fortune.com/2015/03/26/3-things-millennials-want-in-a-career-hint-its-not-more-money /, March 26, 2015 (Visited October 20, 2015)

Mitchell, G. W., L. B. Skineer, \& B. J. White. (2010). Essential soft skills for success in the twenty-first century workforce as perceived by business educators, The Delta pi Epsilon Journal, volume LII, No. 1, winter

Orr, Claudia, Bruce Sherony, and Carol Steinhaus. (2011). Employer perceptions of student informational interviewing skills and behaviors, American Journal of Business Education, December, volume 4, number 12

Robinson, J. S. (2009). Assessing the employability skills of university of Kentucky college of agriculture graduates: A comparison of hard and soft science disciplines. NACTA Journal, December

Simon, Cecilla Capuzzi. (2012, Nov 2). Major Decisions, The New York Times, http://www.nytimes.com/2012/11/04/education/edlife/choosing-one-college-major-out-of-hun dreds.html (Visited October 21, 2015)

Taylor, Kate. (2013). Why Millennials are ending the 9 to 5, Forbes Magazine Online http://www.forbes.com/sites/katetaylor/2013/08/23/why-millennials-are-ending-the-9-to-5/, August 23, 2013 (Visited October 20, 2015)

White, Gillian. Millennials in search of a different kind of career, The Atlantic http://www.theatlantic.com/business/archive/2015/06/millennials-job-search-career-boomers/ 395663/, June 12, 2015 (Visited October 20, 2015)

\section{Copyright Disclaimer}

Copyright for this article is retained by the author(s), with first publication rights granted to the journal.

This is an open-access article distributed under the terms and conditions of the Creative Commons Attribution license (http://creativecommons.org/licenses/by/3.0/). 